\title{
FOOD PRODUCTS PLACEMENT DURING COVID-19 PANDEMIC
}

\author{
Sonja R. Vučenović, Daniela P. Nuševa, Dražen S. Marić, Radenko M. Marić*, Goran M. Vukmirović, Ksenija \\ P. Leković
}

University of Novi Sad, Faculty of Economics in Subotica, 24000 Subotica, Segedinski put 9 - 11, Serbia

\begin{abstract}
The COVID-19 pandemic has entirely changed the patterns of behavior in the market. Physical distance, quarantine measures, safety and security protocols, and shortages along the entire supply chain, have particularly affected the placement of food products. In this regard, the paper aims to define the impact of various indicators on the placement of food products during the COVID-19 pandemic. An empirical study was conducted on a sample of 248 final consumers. The survey was conducted during the third wave of the COVID-19 pandemic in the territory of the Republic of Serbia (February - April 2021). An online questionnaire was created and forwarded to consumers to e-mail addresses from the collected databases of trade companies covering the domestic market. The analysis was performed specifically for four groups of essential food products in a pandemic: meat and meat products, fruit and vegetables, milk and dairy products, cereals, and cereal products. The method of structural modeling (SEM) or path analysis was applied to test the first group of research hypotheses on the impact of indicators on the placement of food products. Multiple regression analysis was used to examine the correlation between subcategories of food products. The results showed a statistically significant impact of indicators such as safety and security standards, hygiene, product freshness, nutritional composition, and product quality. The impact of these indicators differs significantly depending on the analyzed product group. The obtained results indicate to the supply chain management which negative impacts need to be minimized to ensure timely placement of food products and more efficiently meet the needs of final consumers in a pandemic. Guidelines for future research are listed in the paper.
\end{abstract}

Key words: food products placement, supply chain, COVID-19 pandemic, consumer behavior

\section{INTRODUCTION}

In academic research in recent years, there has been a noticeable expansion of papers dealing with the issue of abrupt market fluctuations and large shocks on the supply and demand side. The effects of natural disasters on food shortages (Dubey \& Anjora, 2021), the influence of political and economic crises on the market supply of basic foodstuffs (Kristof- fersen, 2021), the impact of rapid population growth and globalization on food and water shortages (Maheshwari, 2021), problems of stockpiling due to panic and fear are all analyzed (Paduloh \& Djatna, 2021). As an additional problem, the COVID-19 pandemic emerged, which fundamentally changed consumer habits, disrupted the supply chain, and 
caused unforeseeable shocks on the demand side, primarily for food, drugs, and medical equipment (Debata, Patnaik \& Mishra, 2020). The consequences of the impact of the pandemic on the economy are still incalculable. The results show that restrictions on deliveries were caused by large-scale shortages of fresh fruit and vegetables, meat, fish, and other perishable products (Eftimov, Popovski, Petković, Seljak \& Kocev, 2020). In 2020, global meat consumption fell by 3\% (Paduloh \& Djatna, 2021), large fruit and vegetable shortages were observed in underdeveloped countries, panicked stockpiling, whereas $86 \%$ of food chain participants reported some unforeseen situations which delayed placement (Richards \& Rickard, 2020). On the other hand, consumers' fear of infection, self-isolation, and quarantine measures have drasticcally affected the change in consumer habits and the rapid growth of online shopping. Some studies show an increase in online food purchases during the pandemic of as much as $66.7 \%$ (Ćirić, Ilić, Ignjatijević \& Brkanlić, 2020).

The progress of the pandemic directly affects the smooth functioning of the food supply chain, primarily the ability of farmers, food manufacturers, distributors, and retailers to develop their business in changed conditions, jeopardizing the survival of these companies and jeopardizing the sustainability of the entire food distribution system (de Paulo Farias, \& dos Santos Gomes, 2020). Behavioral patterns have changed, not only during the purchase but also the satisfaction after the purchase. There is a fear of choosing contaminated food, doubts about the safety, hygiene, and freshness of products (Laborde, Martin, Swinnen \& Vos, 2020). At the same time, due to the fear of shortages, consumers accumulate food stocks in panic and thus cause shortages themselves. By using a multi-channel approach to product placement, the retail chains managed to neutralize these large market fluctuations and provide the necessary quantities of food available (Petković \& Užar, 2020). However, rural regions with micro and small enterprises as the dominant segment of the retail supply are experiencing shortages (Končar, Marić, Vukmirović \& Vučenović, 2021).

Keeping in mind the presented aspects, the subject of this paper is the analysis of the sustainability of food placement in the con- ditions of the COVID-19 pandemic. It is necessary to look at the patterns of behavior of final consumers and adjust the placement to their needs. As the most significant indicators that shape the placement and affect the final consumers in a pandemic, the authors identify: food safety and security standards (Lacombe, Quintela, Liao \& Wu, 2021), food hygiene (Finger et al., 2021), price (Hobbs, 2020), product freshness (Hobbs, 2020; Lacombe et al., 2021), nutritional composition (Naja \& Hamadeh, 2020), chain transparency (Končar et al., 2021) and food quality (Končar, Grubor, Marić, Vukmirović \& Đokić, 2019; Galanakis, 2020; Hobbs, 2020). This paper aims to define the impact of the abovementioned indicators on the food products placement during the COVID-19 pandemic. The impact of each indicator was analyzed and defined for four groups of essential food products in pandemic conditions, such as meat and meat products, fruit and vegetables, milk and dairy products, cereals, and cereal products. The practical significance of the paper includes a proposal of guidelines, measures, and recommendations to the supply chain management on what negative impacts to minimize to ensure timely food placement and more efficiently meet the needs of final consumers in conditions of large-scale market shocks. The originality of the paper lies in filling the research gap that exists in academic studies due to the lack of research dealing with these issues in the market of the Republic of Serbia and the Western Balkans.

\section{THEORETICAL BACKGROUND}

In the period preceding the economic crisis caused by the COVID-19 virus, the global market was characterized by low fluctuations, with a stable supply chain based on the application of the 7P approach in distribution, with relatively low stocks and continuous food flow (Chenarides, Manfredo \& Richards, 2021). Most pre-covid studies emphasize precisely the flexibility of the supply chain and its ability to respond to all market needs (Anđelković \& Radosavljević, 2018; Trigeorgis \& Tsekrekos, 2018). However, the proclamation of a global pandemic fundamentally changes the previous theoretical stronghold. The pandemic has shown that the existing flexibility of food supply chains is not effective in the circumstances of sudden shocks (Rizou, Galanakis, Aldawoud \& Galanakis, 2020; Končar et al., 2021). 
Studies (Sheth, 2020; Stanciu, Radu, Sapira, Bratoveanu \& Florea, 2020) highlight significant changes in the patterns of behavior of final consumers. The biggest consumer problems are distrust in protection systems, the danger of food contamination, hygiene, mandatory physical distance in stores, use of personal protective equipment, etc. As a result of such patterns during the first wave of the pandemic (March-May 2020), a drastic decline in sales in traditional food stores ranged from $32 \%$ (China) to as much as $-80 \%$ (Mexico) (Končar et al., 2021). Consumers are redirectting much of their activities to e-retail and food purchases via the Internet. It is estimated that e-retail sales recorded a 50\% higher growth compared to the months before the pandemic (Dannenberg, Fuchs, Riedler \& Wiedemann, 2020). Studies highlight the following indicators that are considered crucial in food placement and timely meeting the needs of final consumers in situations of large-scale market shocks:

Food safety and security standards (Lacombe et al., 2021) - the US Center for Disease Control and Prevention (CDC) has not confirmed so far that food consumption is associated with the COVID-19 virus (Center for Disease Control and Prevention, 2020). However, until transmission mechanisms are investigated in detail, experts still believe the traditional approach to food safety will not be sufficient (Kang et al., 2020; Shahidi, 2020). Hence, it is necessary to introduce clear standards and protocols for control, processing, testing, traceability, and distribution of food along the entire supply chain, that will be transparently available to final consumers. In addition to all this, existing standards such as HACCP, IFS, BRC, etc. must not be neglected.

Hygiene - most studies confirm that increased awareness of hygiene during a pandemic can have a lasting positive effect on safety (Hobbs, 2020; Finger et al., 2021). This indicator refers to the recommended measures of hygiene and personal protection of workers when handling food. A study (Finger et al., 2021) conducted on a sample of 3,000 respondents found that certain deficiencies directly affect the infection when buying food. These deficiencies include not using face masks in stores (6\%), improper washing and disinfection of hands (10-12\%), use of defective products for food cleaning and disinfection (28\%), etc.
Price is an indicator that directly corresponds to shortages. In addition, it is evident that placement costs are rising due to export restrictions, delays in deliveries, waiting at borders due to various security protocols, problems with the transport of food and raw materials from highly contagious areas, etc. (Cardwell \& Ghazalian, 2020). Rising food prices are difficult to avoid in a pandemic, which further affects final consumers (Hobbs, 2020).

Food freshness - some studies (Enneking, Neumann \& Henneberg, 2007) unequivocally confirm that consumers identify and evaluate food solely based on freshness. Freshness directly depends on the flow rate of raw materials and food within the chain itself. The problem is the impossibility of Just-in-Time delivery due to delays, quarantine, and frequent controls, which directly affects the freshness.

Nutritional composition - previous experiences, and studies (Cobb, 2001; Yousafzai, Rasheed \& Bhutta, 2013) have confirmed that the quality of nutrition helps individuals to strengthen the body's resistance and fight viral infections. The data show that final consumers pay great attention to the nutritional composition and quality of nutrition (Naja \& Hamadeh, 2020). It is necessary to minimize the placement of foods that contain low levels of energy, protein, and specific micronutrients because this leads to a weakening of immune functions and increased susceptibility to infections.

Transparency of the supply chain - there are problems related to difficulties in vertical and horizontal monitoring of products, slow exchange of information between participants, inability to identify critical points, issues related to food safety, hygiene of machines and workers, etc. (Končar et al., 2021). This information must be available to final consumers so that from their decision to purchase in a pandemic, the possibility of choosing contaminated food is eliminated.

Food quality - quality is the placement indicator most affected by the pandemic. The inability to obtain adequate raw materials and finished products from the regions affected by the pandemic requires the selection of supplements that may compromise the actual, presented quality (Končar et al., 2021). 
Since in the situation of a pandemic, meat and meat products, fruit and vegetables, milk and dairy products, cereals, and cereal products stand out as essential food products, in addition to the unified analysis, it is necessary to analyze the impact of these indicators on each food subcategory.

\section{MATERIALS AND METHODS}

\section{The aim of the research and hypotheses}

The research aims to define the impact of placement indicators such as food safety and security standards, food hygiene, price, food freshness, nutritional composition, supply chain transparency, and food quality on the sustainability of food placement in the COVID-19 pandemic. The impact needs to be analyzed for four subcategories of food products: meat and meat products, fruit and vegetables, milk and dairy products, cereals, and cereal products.

Previous studies have assessed the impact of given indicators differently. Lacombe et al. (2021) consider that the safety standards and protocols are the key indicators, Finger et al. (2021) and Hobbs (2020), emphasize the crucial importance of hygiene in food handling, for Cardwell \& Ghazalian (2020), these are costs, while Končar et al. (2021) emphasize chain transparency, and Naja and Hamadeh (2020), nutritional composition and quality. Accordingly, the impact of these seven indicators will be tested through the first group of research hypotheses:

Hypothesis $\mathbf{H}_{1(a)}$ states that safety and security standards have a statistically significant impact on the placement of food products in the conditions of the COVID-19 pandemic.

Hypothesis $\mathbf{H}_{\mathbf{1}(\mathbf{b})}$ states that food hygiene has a statistically significant impact on the placement of food products in the conditions of the COVID-19 pandemic.

Hypothesis $\mathbf{H}_{1(\mathbf{c})}$ states that the price has a statistically significant impact on the placement of food products in the conditions of the COVID-19 pandemic.

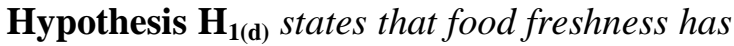
a statistically significant impact on the placement of food products in the conditions of the COVID-19 pandemic.

Hypothesis $\mathbf{H}_{1(\mathrm{e})}$ states that the nutritional composition has a statistically significant effect on the placement of food products in the conditions of the COVID-19 pandemic.

Hypothesis $\mathbf{H}_{\mathbf{1}(\mathbf{f})}$ states that supply chain transparency has a statistically significant impact on food placement in the context of the COVID-19 pandemic.

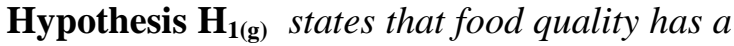
statistically significant impact on the placement of food products in the conditions of the COVID-19 pandemic. The authors (Hobbs, 2020; Končar et al., 2021; Finger et al., 2021) are of the opinion that there are subcategories of food products that are essential during sudden market shocks (e.g., pandemics, war, natural disasters, etc.). If this position is accepted, it is necessary to conduct special testing of the impact of placement indicators for meat and meat products, fruit and vegetables, milk and dairy products, cereals, and cereal products. In this context, a second research hypothesis has been set.

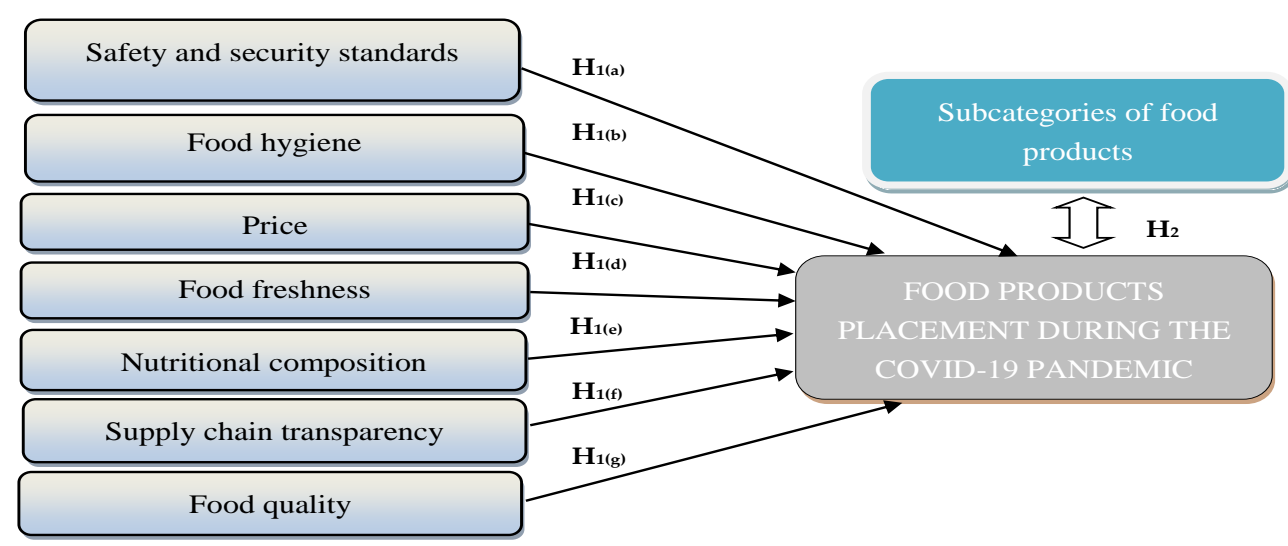

Figure 1. Research model 
Hypothesis $\mathbf{H}_{2}$ states that differences between subcategories of food products that are essential during periods of extensive market shocks are statistically significant in predicting differences in the impact of food safety and security standards, food hygiene, price, freshness, nutritional composition, supply chain transparency, and food quality on the sustainability of food products placement in a COVID19 pandemic.

The set research goal and research hypotheses are presented in the following research model (Fig. 1).

\section{Research variables}

The study includes one dependent variable and several independent variables based on the research goal and research hypotheses. The dependent variable is the placement of food products in the conditions of the COVID-19 pandemic, which is estimated based on three statements of Likert's type of ranking (grades 0 5). Independent variables of interval type of measurement are placement indicators: food safety and security standards, food hygiene, price, freshness, nutritional composition, transparency of the supply chain, and food quality (Cardwell \& Ghazalian, 2020; Hobbs, 2020; Naja \& Hamadeh, 2020; Finger et al., 2021; Končar et al., 2021; Lacombe et al. 2021). Independent grouping variables are analyzed subcategories of food products (meat and meat products, fruit and vegetables, milk and dairy products, cereals, and cereal products). Each of the independent variables was estimated through three statements based on the Likerttype interval (impact on food quality, impact on health and safety and impact on product availability and range).

\section{Research sample}

The survey was conducted on a sample of 248 final consumers, which makes it is a convenience sample (Schönbrodt \& Perugini, 2013). The sample structure is uniform across all demographic categories so that the most relevant answers of respondents can be obtained (Table 1). The reliability of the sample, i.e., the correctness of the selected scales was confirmed by Cronbach's alpha, Skewness, and Kurtosis coefficients (Table 2).

Since the Cronbach's alpha values for all indicators are above 0.750 and no statistically significant deviations are observed in the Skewness and Kurtosis coefficients which confirmed the accuracy of the selected scales. In other words, the chosen questions describe an identical problem and can be used to examine the attitudes of final consumers regarding the sustainability of food products placement.

\section{Research procedure and data analysis}

The final consumer survey was conducted during the third wave of the COVID-19 pandemic in the territory of the Republic of Serbia (February - April 2021). An online questionnaire (Google Forms) was created and forwarded to consumers to e-mail addresses from the collected databases of trade companies covering the domestic market.

The questionnaire was structured based on similar research (Cardwell \& Ghazalian, 2020; Hobbs, 2020; Naja \& Hamadeh, 2020; Finger et al., 2021; Končar et al., 2021; Lacombe et al. 2021).

Table 1.

Sample structure

\begin{tabular}{lcc}
\hline Gender of respondents & $\mathbf{n}$ & Structure $(\boldsymbol{\%})$ \\
\hline Female & 134 & 54.03 \\
Male & 114 & 45.97 \\
Level of Education & & 25.81 \\
Primary and secondary education & 64 & 34.27 \\
College degree & 85 & 39.92 \\
University degree & 99 & 20.56 \\
Household income & & 50.40 \\
up to $€ 500$ & 51 & 29.04 \\
from $€ 500$ to $€ 1,000$ & 125 & \\
over $1,000 €$ & 72 & \\
\hline
\end{tabular}

Source: Authors 
Table 2.

Coefficients of sample reliability tests

\begin{tabular}{lccc}
\hline Indicators & $\begin{array}{c}\text { Cronbach's } \\
\text { alpha }\end{array}$ & Kurtosis & Skewness \\
\hline Safety and security standards & 0.807 & -1.120 & 0.079 \\
Food hygiene & 0.914 & -1.017 & -0.228 \\
Price & 0.768 & -0.983 & 0.440 \\
Food freshness & 0.773 & -0.891 & -0.529 \\
Nutritional composition & 0.895 & -1.112 & -0.212 \\
Supply chain transparency & 0.945 & -0.729 & 0.057 \\
Food quality & 0.903 & -0.848 & -0.328 \\
\hline
\end{tabular}

Source: Authors

Table 3.

Descriptive statistics for selected indicators

\begin{tabular}{llccccc}
\hline $\begin{array}{l}\text { Order } \\
\text { no. }\end{array}$ & \multicolumn{1}{c}{ Indicators } & Min. & Max. & $\begin{array}{c}\text { Mean } \\
(\mathbf{M})\end{array}$ & $\begin{array}{c}\text { Standard } \\
\text { Error } \\
\text { (SE) }\end{array}$ & $\begin{array}{c}\text { Standard } \\
\text { Deviation } \\
\text { (SD) }\end{array}$ \\
\hline $\mathbf{1}$ & \multicolumn{1}{c}{$\mathbf{2}$} & $\mathbf{3}$ & $\mathbf{4}$ & $\mathbf{5}$ & $\mathbf{6}$ & $\mathbf{7}$ \\
\hline 1 & Safety and security standards & 2.00 & 5.00 & 4.23 & 0.0825 & 1.0235 \\
2 & Food hygiene & 1.00 & 5.00 & 3.48 & 0.0849 & 1.0800 \\
3 & Price & 1.00 & 4.00 & 3.01 & 0.0705 & 1.0736 \\
4 & Food freshness & 2.00 & 5.00 & 4.08 & 0.0692 & 0.9338 \\
5 & Nutritional composition & 1.00 & 5.00 & 3,37 & 0.0110 & 1.1425 \\
6 & Supply chain transparency & 1.00 & 5.00 & 3.28 & 0.0850 & 0.9519 \\
7 & Food quality & 1.00 & 5.00 & 4.11 & 0.1665 & 1.2824 \\
\hline
\end{tabular}

Source: Author's calculation

Table 4.

Testing the contribution of individual indicators

\begin{tabular}{|c|c|c|c|c|}
\hline & \multicolumn{2}{|c|}{ Stand. coefficient } & \multirow{2}{*}{$t$} & \multirow{2}{*}{ Sig. } \\
\hline & Beta & St. Error & & \\
\hline (const.) & 0.768 & 1.183 & 3.648 & 0.001 \\
\hline Safety and security standard & $0.779 * *$ & 0.722 & 1.238 & 0.004 \\
\hline Food hygiene & $0.785^{*}$ & 0.695 & 0.854 & 0.039 \\
\hline Price & -0.435 & 0.693 & 0.712 & 0.238 \\
\hline Food freshness & $0.618 * *$ & 0.711 & 1.238 & 0.008 \\
\hline Nutritional composition & 0.829 & 0.960 & 0.275 & 0.078 \\
\hline Supply chain transparency & -0.173 & 0.456 & 1.130 & 0.551 \\
\hline Food quality & $0.754 * *$ & 0.694 & 0.605 & 0.000 \\
\hline
\end{tabular}

** Correlation is significant at the level 1\%, * Correlation is significant at the level 5\%,

Source: Author's calculation

After giving general demographic information, respondents ranked the impact of each selected indicator by using the Likert scale (0-no significance; 5-very high significance). The return rate of the questionnaire is $31 \%$ (248/800).

Statistical package for social sciences SPSS 20 was used for processing and analysis of the collected data. The Descriptive Statistics method was used to describe the sample. The method of structural modeling (SEM) or path analysis was applied to test the first group of research hypotheses on the impact of indicators on the placement of food products. Multiple regression analysis was used to examine the correlation between subcategories of food products. 


\section{RESULTS}

The results of the respondents' answers, that is, the degree of agreement with the statement that the analyzed indicators influence the placement of food products in the COVID-19 pandemic, are presented in Table 3. The table illustrates the average scores for each indicator as well as the most significant features of descriptive statistics.

Respondents give the highest average score to safety and security standards $(\mathrm{M}=4.23)$, as crucial for sustainable food placement in a pandemic. Followed by food quality $(\mathrm{M}=$ 4.11) and its freshness (4.08). The minimal deviation between the respondents' answers is read in the indicators of freshness (SD = 0.9338 ) and safety and security standards (SD $=1.0235$ ).

That indicates that respondents generally agree on the importance that these indicators have on placement. An interesting result is that the price has the lowest average value $(\mathrm{M}=3.01)$, which implies that consumers are willing to pay more for a safe product. Also, any increase in market demand dictates the growth of prices, so this result is realistic, bearing in mind that consumers expect the price increase in periods of market shocks. Nevertheless, the supply chain needs to be flexible enough to fill all the gaps on the demand side, eliminate shortages, and thus minimize any price increase.

For a precise analysis of the impact of the analyzed indicators on the placement of food products in a pandemic, it is necessary to test the first group of research hypotheses $\mathbf{H}_{\mathbf{1}(\mathbf{a})}$ -

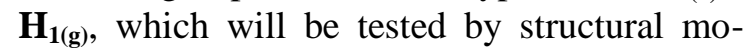
deling (SEM) or path analysis. First, it is necessary to determine the existence of a correlation between the observed indicators and placement. Multiple regression analysis was applied - the "Enter" method, which combines all independent indicators into predicting the dependent variable (placement of food products).

The obtained model is statistically significant $(\mathrm{F}(200 ; 6)=2.802, \mathrm{p}<0.01)$, which means that the set of tested indicators statistically significantly predicts the placement of food products in the conditions of the COVOD-19 pandemic. The set model describes $69.4 \%$ of the variance of the criteria. The individual con- tribution of the indicator is illustrated in Table 4.

The results suggest that safety and security standards $(\beta=0.779 ; p<0.01)$, quality $(\beta=$ $0.754 ; p<0.01)$ and food freshness $(\beta=0.618$; $\mathrm{p}<0.01)$ are statistically significant in predicting the placement of food products under COVID-19 pandemic. These results coincide with previous studies that consider these indicators as factors that are the most responsible for placement (Enneking, Neumann \& Henneberg, 2007; Končar et al., 2019; Kang et al., 2020; Shahidi, 2020; Lacombe et al., 2021). The existing correlation is positive, meaning that with the increase in the intensity of the influence of these indicators, the efficiency of placement increases. Food hygiene is somewhat less important $(~(\beta=0.785 ; p<0.05)$, while other indicators have no statistical significance ( $>>0.05)$.

As the focus of the work is on testing the set hypotheses and defining the impact of indicators on the placement of food products, Table 5 shows the results of the Path analysis, where based on the set paths, we can see the impact of individual indicators. The results show a satisfactory fit of the model $(\mathrm{NFI}=$ $0.945, \mathrm{RFI}=0.937, \mathrm{IFI}=0.961, \mathrm{TLI}=0.984$, $\mathrm{CFI}=0.990, \mathrm{RMSEA}=0.028, \mathrm{CMIN} / \mathrm{DF}=$ 1.386).

Testing showed that the placement of food products is under the direct influence of the standards of safety and security, food hygiene, freshness, and quality. That means that research hypotheses $\mathbf{H}_{1(\mathbf{a})}, \mathbf{H}_{\mathbf{1}(\mathrm{b}),}, \mathbf{H}_{\mathbf{1}(\mathrm{d})}$ and $\mathbf{H}_{\mathbf{1}(\mathrm{g})}$ are accepted. There is a statistically significant impact of safety and security standards on food quality, freshness, and hygiene. Hygiene significantly affects freshness and quality, while nutritional composition has an evident influence on food quality. For other indicators, no statistically significant impact on the placement of food products was found, which indicates that the research hypotheses $\mathbf{H}_{1(\mathbf{c})}, \mathbf{H}_{\mathbf{1}(\mathbf{e})}$ and $\mathbf{H}_{1(\mathbf{f})}$ are rejected. The following graph (Fig. 2) is a structural model, that is, an illustration of the impact of the analyzed indicators on the placement of food products in the COVID-19 pandemic. Given that certain categories of food products such as meat and meat products, fruit and vegetables, milk and dairy products, cereals and cereal products, are considered essential during periods of large mar- 
ket fluctuations and shocks on the demand side, it is necessary to test the impact of indicators separately for each of these categories. For investigating the $\mathbf{H}_{\mathbf{2}}$ hypothesis, multiple regression analysis was applied. The obtained regression model is statistically significant for each of the observed categories. For meat and meat products $(\mathrm{F}(200 ; 6)=2.802, \mathrm{p}<0.01)$, the model describes $74.3 \%$ of the variance of the criteria, for fruit and vegetables $(\mathrm{F}(200 ; 6)$ $=2.802, \mathrm{p}<0.01)$, the model describes $54.5 \%$ variance of the criteria, for milk and dairy products $(\mathrm{F}(200 ; 6)=2.802, \mathrm{p}<0.05)$, the model describes $46.5 \%$ of the variance of the criteria for both cereals and cereal products ( $\mathrm{F}$ $(200 ; 6)=2.802, \mathrm{p}<0.01)$, the model describes $70.4 \%$ of the variance of the criteria. If we look individually at meat and meat products, the greatest significance is read for freshness $(\beta=0.617, p<0.01)$ and safety and security standards $(\beta=0.784, p<0.01)$. In fruit and vegetables, freshness $(\beta=0.507, \mathrm{p}<0.01)$ and hygiene $(\beta=0.512, \mathrm{p}<0.05)$ are the most important, and in milk and dairy products it is the nutritional composition $(\beta=0.852$, $\mathrm{p}<0.01)$. The most important standards for the placement of cereals and cereal products are safety and security $(\beta=0.718, \mathrm{p}<0.01)$ and quality $(\beta=0.667, \mathrm{p}<0.01)$.

From the above models, it is evident that the indicators have a different impact on the placement depending on the food category. We conclude that the second research hypothesis $\mathbf{H}_{\mathbf{2}}$ is accepted and that the differences between the subcategories of food products essential in periods of large market shocks statistically significantly predict the differences that appear in the impact of indicators on food placement in the COVID-19 pandemic.

Table 5.

Results of path analysis

\begin{tabular}{|c|c|c|c|c|}
\hline $\begin{array}{c}\text { Ord. } \\
\text { no. }\end{array}$ & Path & $\begin{array}{c}\text { Path } \\
\text { coefficient }\end{array}$ & $\begin{array}{c}\mathbf{T} \\
\text { value }\end{array}$ & Result \\
\hline 1 & 2 & 5 & 6 & 7 \\
\hline 1 & Safety and security standards » food products placement & 0.882 & 15.221 & Support \\
\hline 2 & Safety and security standards» food hygiene & 0.572 & 5.151 & Support \\
\hline 3 & Safety and security standards » price & 0.364 & 3.077 & Reject \\
\hline 4 & Safety and security standards » food freshness & 0.448 & 10.03 & Support \\
\hline 5 & Safety and security standards $»$ nutritional composition & 0.121 & 1.835 & Reject \\
\hline 6 & Safety and security standards » supply chain transparency & 0.056 & 11.250 & Reject \\
\hline 7 & Safety and security standards » food quality & 0.851 & 1.718 & Support \\
\hline 8 & Food hygiene $»$ food products placement & 0.561 & 15.001 & Support \\
\hline 9 & Food hygiene » price & 0.277 & 3.144 & Reject \\
\hline 10 & Food hygiene » food freshness & 0.648 & 9.16 & Support \\
\hline 11 & Food hygiene $»$ nutritional composition & 0.184 & 3.527 & Reject \\
\hline 12 & Food hygiene $»$ supply chain transparency & 0.537 & 8.480 & Reject \\
\hline 13 & Food hygiene » food quality & 0.754 & 10.908 & Support \\
\hline 14 & Price $»$ food products placement & 0.044 & 0.998 & Reject \\
\hline 15 & Price $»$ food freshness & 0.579 & 10.113 & Reject \\
\hline 16 & Price $»$ nutritional composition & 0.088 & 1.835 & Reject \\
\hline 17 & Price $»$ supply chain transparency & 0.706 & 11.360 & Reject \\
\hline 18 & Price $»$ food quality & 0.082 & 1.718 & Reject \\
\hline 19 & Food freshness » food products placement & 0.771 & 15.511 & Support \\
\hline 20 & Food freshness » nutritional composition & 0.277 & 3.144 & Support \\
\hline 21 & Food freshness » supply chain transparency & 0.648 & 9.033 & Support \\
\hline 22 & Food freshness » food quality & 0.184 & 3.527 & Support \\
\hline 23 & Nutritional composition $»$ food products placement & 0.054 & 0.728 & Reject \\
\hline 24 & Nutritional composition $»$ supply chain transparency & 0.537 & 8.424 & Reject \\
\hline 25 & Nutritional composition $»$ food quality & 0.424 & 0.998 & Support \\
\hline 26 & Supply chain transparency » food products placement & 0.224 & 0.818 & Reject \\
\hline 27 & Supply chain transparency » food quality & 0.054 & 0.984 & Reject \\
\hline 28 & Food quality $»$ food products placement & 0.637 & 8.303 & Support \\
\hline
\end{tabular}




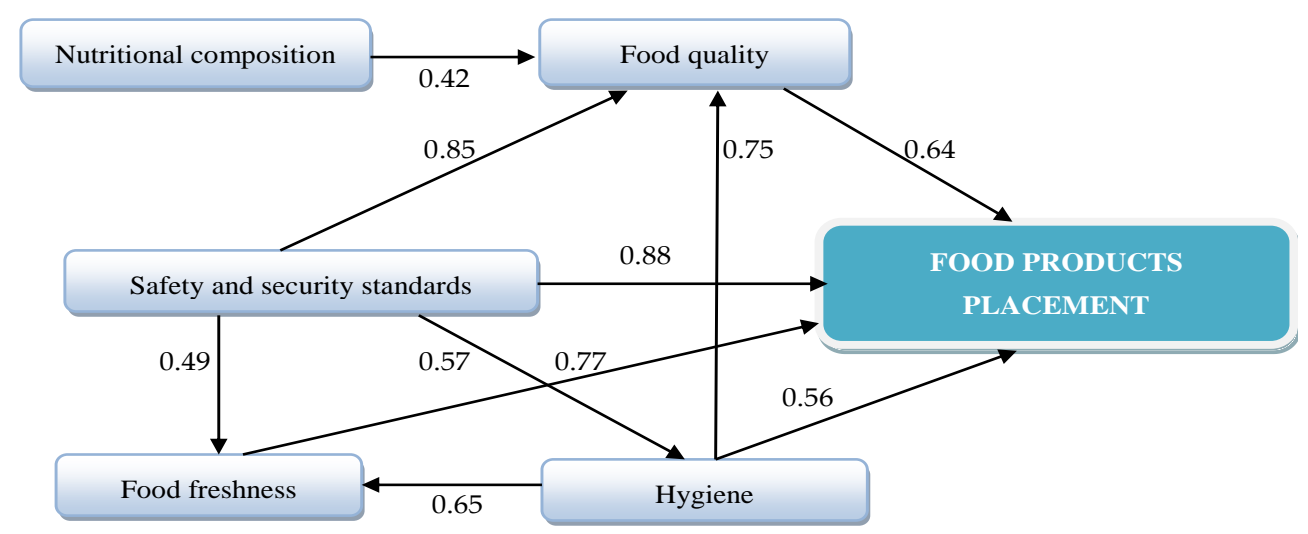

Figure 2. Structural model

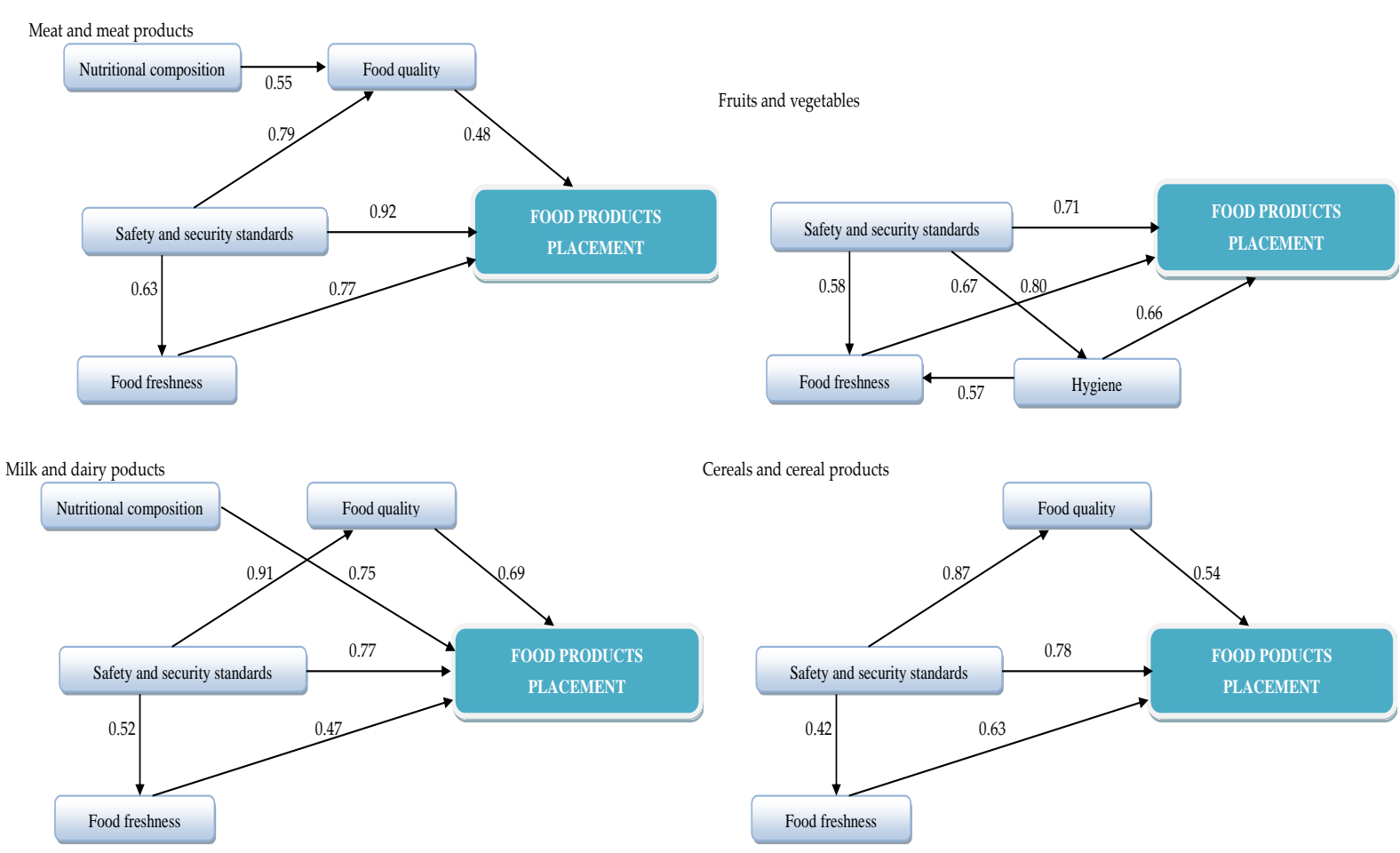

Figure 3. Structural models for food product categories

\section{DISCUSSION}

The research has shown that defined indicators significantly shape the placement of food products in periods of large-scale and sudden shocks on the demand side, such as the COVID-19 pandemic. The pandemic has fundamentally changed consumer behavior habits, such as health concerns, panicked stockpiling, and minimizing physical contact. As a result of such patterns of behavior, research has confirmed the assumptions of some earlier studies (Enneking, Neumann \& Henneberg, 2007;
Končar et al., 2029; Kang et al., 2020; Shahidi, 2020; Lacombe et al., 2021) that food placement in a pandemic is under the direct influence of safety and security standards, hygiene, food freshness, and quality. An interesting result is that price does not play a significant role. Final consumers seem to be aware that various epidemiological and antipandemic measures imposed by different countries hinder the movement of people, raw materials, and finished products. They also know that there are frequent cases of mandatory quarantine, waiting at border crossings, 
complicated transport procedures, etc. The placement of food products thus becomes more expensive, costs and delivery times increase, which directly increases the price of food. These results are confirmed by recent studies (Akter, 2020; Cardwell \& Ghazalian, 2020). Also, this research has shown that final consumers do not pay as much attention to supply chain transparency and nutritional composition. Individually, observed by subcategories, the indicators show certain deviations in the impact. For example, the nutritional composition has a significant influence on the placement of milk and dairy products. Hygiene is most important in fruit and vegetables, etc.

With the obtained results in mind, we can propose three types of measures and incentives to boost the indicators that shape the placement. These are financial incentives, anti-pandemic measures, and organizational procedures.

Financial incentives - competent institutions, chambers of commerce, ministries should reduce fixed costs along the food supply chain. Some of the measures relate to tax relief, more favorable lending conditions, and direct financial incentives. Part of the measures should be focused on the possibility of deferred payment, reimbursement of costs incurred due to delays at the borders, investments in the modernization of production processes and facilities. A particular problem is the retention of workers and new employment, where incentives should be made in the form of reduced taxes and contributions, more active participation of the state in employment programs, etc.

Anti-pandemic measures - all participants in the supply chain should clearly define new standards, procedures, and protocols for the safe transfer of food along the entire chain. Existing standards such as HACCP, IFC, BRC need to be reviewed and upgraded with special safety measures to minimize the risk of food contamination and human infection with the COVID-19 virus. All participants, especially retailers at the point of final food sales, should have internal documents in the form of antipandemic protocols, clearly indicated ways of behavior of consumers and employees in sales facilities, with all possible use of barriers, glass barriers, protective equipment, etc.
Organizational procedures - supply chain management should develop an awareness of adaptation to current market flows. That means that all employees should adhere to safety protocols to the maximum, especially employyees who are in direct contact with and who handle food. It is necessary to take care of the employees' health, strengthen managerial efforts in maintaining the same level of quality, allocate the most skilled people to critical places of contamination (e.g., packing fresh meat), etc. Equipment, machines, work surfaces, and facilities must be continuously cleaned, disinfected, and ventilated.

Only by applying these measures and incentives is it possible to increase the flexibility of the supply chain, increase the satisfaction of final consumers and make the final purchase safer. At the same time, electronic channels need to be developed and an increasing number of food products made available to consumers on their doorstep. Only those participants in the supply chain who adapt to the new reality on time and transform their business will succeed, making the placement of food products completely sustainable even in extreme, unforeseen circumstances such as the COVID-19 pandemic.

\section{CONCLUSIONS}

The need for research stemmed from the fact that we are witnessing disrupted flows of food products on the market as a result of the COVID-19 pandemic. The danger of infection at the point of sale, doubts about the quality of food, and the consumers' fear from shortages, which turned into a panicked accumulation of stocks, have completely disrupted the supply chain. The present flexibility has not proved to be effective, and the sustainability of the placement has been impaired.

This research aimed to determine which indicators are crucial for food placement. In this context, research hypotheses were set and tested by SEM method or Path analysis. The hypotheses that safety and security standards, hygiene, food freshness, and food quality have a statistically significant impact have been confirmed. The nutritional composition has slightly less importance. Based on the obtained results, we proposed measures and incentives to encourage and focus all participants in the chain to strengthen these indicators. 
The shortcomings of research are reflected in the geographical limitations on the market of the Republic of Serbia. The objective reason for choosing such a sample is the impossibility to conduct this research outside the domestic borders due to epidemiological measures that differ from country to country. Another reason for the choice is the author's familiarity with the flows of food products in the domestic market. Another shortcoming could be the way of structuring the questionnaire, where the respondents responded to pre-prepared statements, which could lead to biased conclusions.

Guidelines for future research - it is necessary to broaden the sample and compare the obtained results with the countries of the region, that is, the Western Balkans and the European Union. The structure of the respondents should also include employees in the food supply chain, managers of retail facilities, farmers, manufacturers, etc. In that way, the academic and scientific contribution to this topic would be completed.

\section{REFERENCES}

Akter, S. (2020). The impact of COVID-19 related 'stayat-home' restrictions on food prices in Europe: findings from a preliminary analysis. Food Security 2020, 12(4), 719-725. https://doi.org/10.1007/s12571-020-01082-3

Anđelković, A., \& Radosavljević, M. (2018). Improving order-picking process through implementation of warehouse management system. Strategic Management - International Journal of Strategic Management and Decision Support Systems in Strategic Management, 23(1), 3-10.

https://www.smjournal.rs/index.php/home/article/vi ew/17/1

Cardwell, R., \& Ghazalian, P. L. (2020). COVID-19 and International Food Assistance: Policy proposals to keep food flowing. World Development, 135, 105059.

https://doi.org/10.1016/j.worlddev.2020.105059

Ćirić, M., Ilić, D., Ignjatijević, S., \& Brkanlić, S. (2020). Consumer behaviour in online shopping organic food during the Covid-19 pandemic in Serbia. Food and Feed Research, 47(2), 149-158. http://doi.org/10.5937/ffr47-28815

Chenarides, L., Manfredo, M., \& Richards, T. J. (2021). Covid-19 and food supply chains. Applied Economic Perspectives and Policy, 43(1), 270-279. https://doi.org/10.1002/aepp.13085

Center for Disease Control and Prevention (2020). Meat and poultry processing workers and employers, Atlanta: CDC.

https://www.cdc.gov/coronavirus/2019ncov/community/organizations/meat-poultryprocessing-workers-employers.html
Cobb, T. D. (2001). Reclaiming our food: how the grassroots food movement is changing the way we eat. Adams, MA, USA: Storey Publishing.

Dannenberg, P., Fuchs, M., Riedler, T., \& Wiedemann, C. (2020). Digital transition by COVID-19 pandemic? The German food online retail. Tijdschrift voor economische en sociale geografie, 111(3), 543-560. https://doi.org/10.1111/tesg.12453

Debata, B., Patnaik, P., \& Mishra, A. (2020). COVID-19 pandemic! It's impact on people, economy, and environment. Journal of Public Affairs, 20(4), e2372. https://doi.org/10.1002/pa.2372

de Paulo Farias, D., \& dos Santos Gomes, M. G. (2020). COVID-19 outbreak: What should be done to avoid food shortages?. Trends in Food Science \& Technology, 102, 291-292. http://10.1016/j.tifs.2020.06.007

Dubey, M., \& Anjora, D. (2021). Nutritional management of livestock during scarcity. In S. K. Maiti, M. K. Gendley \& Shahaji Phand, (Eds.) Approaches for improving livestock productivity through nutrition and animal health management, (pp. 24-30). Hyderabad, India: National Institute of Agricultural Extension Management - MANAGE. https://www.manage.gov.in/publications/eBooks/li vestock.pdf\#page $=31$.

Enneking, U., Neumann, C., \& Henneberg, S. (2007). How important intrinsic and extrinsic product attributes affect purchase decision. Food Quality and Preference, 18(1), 133-138. https://doi.org/10.1016/j.foodqual.2005.09.008

Eftimov, T., Popovski, G., Petković, M., Seljak, B. K., \& Kocev, D. (2020). COVID-19 pandemic changes the food consumption patterns. Trends in Food Science \& Technology, 104, 268-272. https://doi.org/10.1016/j.tifs.2020.08.017

Finger, J. A. F. F., Lima, E. M. F., Coelho, K. S., Behrens, J. H., Landgraf, M., Franco, B. D. G. M., \& Pinto, U. M. (2021). Adherence to food hygiene and personal protection recommendations for prevention of COVID-19. Trends in Food Science \& Technology, 112, 847-852. https://doi.org/10.1016/j.tifs.2021.03.016

Galanakis, C. M. (2020). The food systems in the era of the coronavirus (COVID-19) pandemic crisis. Foods, 9(4), 523. https://doi.org/10.3390/foods9040523

Gleeson, M., Nieman, D. C., \& Pedersen, B. K. (2004). Exercise, nutrition and immune function. $J$ Sports Sci., 22, 115-125. https://doi.org/10.1080/0264041031000140590

Hobbs, J. E. (2020). Food supply chains during the COVID- 19 pandemic. Canadian Journal of Agricultural Economics/Revue canadienne d'agroeconomie, 68(2), 171-176. https://doi.org/10.1111/cjag.12237

Kang, S., Peng, W., Zhu, Y., Lu, S., Zhou, M., Lin, W., \& Deng, M. (2020). Recent progress in understanding 2019 novel coronavirus (SARS-CoV-2) associated with human respiratory disease: Detection, mechanisms and treatment. International Journal of Antimicrobial Agents, 55(5), 105950. https://doi.org/10.1016/j.ijantimicag.2020.105950

Končar, J., Marić, R., Vukmirović, G., \& Vučenović, S. (2021). Sustainability of Food Placement in Retailing during the COVID-19 Pandemic. Sustainability, 13(11), 5956. 
https://doi.org/10.3390/su13115956.

Končar, J., Grubor, A., Marić, R., Vukmirović, G., \& Đokić, N. (2019). Possibilities to improve the image of food and organic products on the AP Vojvodina market by introducing a regional quality label. Food \& Feed Research, 46(1), 111-123. https://doi.org/10.5937/FFR1901111K

Kristoffersen, D. L. (2021). Venezuela: Political, economic and humanitarian issues. Nova Science $\mathrm{Pu}-$ blisher.

https://pesquisa.bvsalud.org/global-literature-onnovel-coronavirus-2019ncov/resource/pt/covidwho-1344799.

Laborde, D., Martin, W., Swinnen, J., \& Vos, R. (2020). COVID-19 risks to global food security. Science, 369(6503), 500-502. https://doi.org/10.1126/science.abc4765

Lacombe, A., Quintela, I., Liao, Y. T., \& Wu, V. C. (2021). Food safety lessons learned from the COVID-19 pandemic. Journal of Food Safety, 41(2), e12878. https://doi.org/10.1111/jfs.12878

Maheshwari, S. (2021). Vertical Farming: Resilience Towards Climate Change. In A. Kateja \& R. Jain, (Eds.) Urban growth and environmental issues in India (pp. 207-221). Singapore: Springer.

Naja, F., \& Hamadeh, R. (2020). Nutrition amid the COVID-19 pandemic: a multi-level framework for action. European Journal of Clinical Nutrition, 74(8), 1117-1121.

https://www.nature.com/articles/s41430-020-06343?fbclid=IwAR3_Ij9Lus2a_5RwIbXMEztUJZ9vgh0ekc14KrJoz7qmmVrFHhFxzNAxPs.

Paduloh, P., \& Djatna, T. (2021). Proposed reversed supply chain as problem solver for case of returned beef products during the Covid-19 Pandemic. In Proocedings of the $2^{\text {nd }}$ Borobudur International Symposium on Science and Technology (BIS-STE 2020) (pp. 169-173). Magelang, Indonesia. https://www.atlantis-press.com/article/125959955.pdf

Petković, G., \& Užar, D. (2020). Marketing channels in value creation and delivery of cheese in the Re- public of Serbia. Anali Ekonomskog Fakulteta $u$ Subotici, 56(43), 101-115.

https://doi.org/10.5937/AnEkSub2001101P

Richards, T. J., \& Rickard, B. (2020). COVID-19 impact on fruit and vegetable markets. Canadian Journal of Agricultural Economics/Revue canadienne d'agro-economie, 68(2), 189-194. https://doi.org/10.1111/cjag.12231

Rizou, M., Galanakis, I. M., Aldawoud, T. M., \& Galanakis, C. M. (2020). Safety of foods, food supply chain and environment within the COVID-19 pandemic. Trends in Food Science \& Technology, 102, 293-299. https://doi.org/10.1016/j.tifs.2020.06.008.

Sheth, J. (2020). Impact of Covid-19 on consumer behavior: Will the old habits return or die? Journal of Business Research, 117, 280-283. https://doi.org/10.1016/j.jbusres.2020.05.059

Schönbrodt, F. D., \& Perugini, M. (2013). At what sample size do correlations stabilize?. Journal of Research in Personality, 47(5), 609-612. https://doi.org/10.1016/j.jrp.2013.05.009

Stanciu, S., Radu, R. I., Sapira, V., Bratoveanu, B. D., \& Florea, A. M. (2020). Consumer Behavior in Crisis Situations. Research on the Effects of COVID-19 in Romania. Annals of the University Dunarea de Jos of Galati: Fascicle: I, Economics \& Applied Informatics, 26(1), 5-13. https://doi.org/10.35219/eai1584040975.

Shahidi, F. (2020). Does COVID-19 affect food safety and security? Journal of Food Bioactives, 9, 1-3. https://doi.org/10.31665/jfb.2020.9212

Trigeorgis, L., \& Tsekrekos, A. E. (2018). Real options in operations research: A review. European Journal of Operational Research, 270(1), 1-24. https://doi.org/10.1016/j.ejor.2017.11.055

Yousafzai, A. K., Rasheed, M. A., \& Bhutta, Z. A. (2013). Annual research review: improved nutrition - a pathway to resilience. Journal of Child Psychology and Psychiatry, 54, 367-377. https://doi.org/10.1111/jcpp.12019. 


\title{
PLASMAN PREHRAMBENIH PROIZVODA U USLOVIMA COVID-19 PANDEMIJE
}

\author{
Sonja R. Vučenović, Daniela P. Nuševa ${ }^{1}$, Dražen S. Marić, Radenko M. Marić*, Goran M. Vukmirović, Ksenija \\ P. Leković
}

Univerzitet u Novom Sadu, Ekonomski fakultet u Subotici, 24000 Subotica,

Segedinski put 9 - 11, Srbija

\begin{abstract}
COVID-19 pandemija je u potpunosti promenila obrasce ponašanja na tržištu. Fizička distanca, mere karantina, sigurnosni i bezbedonosni protokoli i nestašice, duž celog lanca snabdevanja, naročito su se odrazili na plasman prehrambenih proizvoda. $\mathrm{S}$ tim u vezi, cilj ovog rada je definisanje uticaja različitih indikatora na plasman prehrambenih proizvoda u uslovima COVID-19 pandemije. Sprovedeno je empirijsko istraživanje na uzorku od 248 finalnih potrošača. Istraživanje je sprovedeno tokom trećeg talasa pandemije COVID-19 na teritoriji Republike Srbije (februar - april 2021. godine). Kreiran je onlajn upitnik koji je prosleđen potrošačima na e-mail adrese iz prikupljenih baza trgovačkih preduzeća koja pokrivaju domaće tržište. Analiza je posebno vršena za četri grupe esencijalnih prehrambenih proizvoda u uslovima pandemije: meso i mesne prerađevine, voće i povrće, mleko i mlečni proizvodi, žitarice i proizvodi od žita. Za testiranje prve grupe, hipoteza istraživanja o uticaju indikatora na plasman prehrambenih proizvoda, primenjen je metod Strukturnog modeliranja (SEM) ili Analiza puta. Višestruka regresiona analiza je korišćena za ispitivanje korelacije između potkategorija prehrambenih proizvoda. Rezultati su pokazali statistički značajan uticaj indikatora poput standarda sigurnosti i bezbednosti, higijene, cene, svežine proizvoda, nutritivnog sastava, transparentnosti lanca i kvaliteta proizvoda. Uticaj navedenih indikatora se značajno razlikuje u zavisnosti od analizirane grupe proizvoda. Dobijeni rezultati ukazuju menadžmentu lanca snabdevanja koje negativne uticaje je potrebno minimizirati kako bi se obezbedio pravovremeni plasman prehrambenih proizvoda i efikasnije zadovoljile potrebe finalnih potrošača u uslovima pandemije. Smernice za buduća istraživanja su navedene u radu.
\end{abstract}

Key words: plasman prehrambenih proizvoda, lanac snabdevanja, COVID-19 pandemija, ponašanje potrošača

Received: 13 October 2021/Received in revised form: 17 November 2021/ Accepted: 18 November 2021

Available online: November 2021

This is an open-access article under the CC BY license (http://creativecommons.org/licenses/by/3.0). 